\title{
La Revolución salvadoreña de 1948. Propaganda visual e IMÁgenes
}

\author{
The Salvadoran Revolution of 1948. Visual Propaganda and Images
}

\author{
Luis Gerardo Monterrosa-Cubías*
}

Resumen: En este artículo se examina la propaganda visual producida por el movimiento revolucionario que sostuvo el poder en los años cincuenta del siglo pasado en El Salvador. Para lograr este cometido se contextualizan algunas imágenes publicadas en tres coyunturas: la campaña proselitista de Óscar Osorio, las conmemoraciones de la Revolución de 1948 y los comicios legislativos y municipales de este período. Este artículo representa un intento por incorporar las imágenes y fotografías al trabajo historiográfico e indagar en la intención gubernamental de generar una opinión pública favorable.

Palabras claves: Óscar Osorio, Revolución de 1948, propaganda visual, opinión pública, elecciones.

Abstract: This article examines the visual propaganda produced by the revolutionary movement that held power in the 1950s in El Salvador. To achieve this goal, some of the images published during three periods are contextualized: Oscar Osorio's proselytizing campaign, the commemorations of the 1948 Revolution, and the legislative and municipal elections during this period. This article endeavors to incorporate images and photographs into historiographical work and investigate the government's interest in generating favorable public opinion.

Keywords: Oscar Osorio, 1948 Revolution, visual propaganda, public opinion, electoral events.

\footnotetext{
* Luis Gerardo Monterrosa Cubías. Doctor en Ciencias Sociales y Humanísticas por el Centro de Estudios Superiores de México y Centroamérica de la Universidad de Ciencias y Artes de Chiapas, México. Temas de especialización: historia contemporánea con énfasis en procesos electorales, composición parlamentaria, reformas electorales y relaciones políticas entre México, El Salvador y Guatemala durante el siglo XX. Correo electrónico: gerardomonterrosa20@gmail. com. ORDIC: https://orcid.org/0000-0002-5846-7418.
}

Enviado a dictamen: 10 de abril de 2018

Aprobación: 1 de septiembre de 2018 Revisiones: 1 
L a inestabilidad expresada en protestas opositoras y cuartelazos marcaba la urdimbre política de la región centroamericana a finales de los años cuarenta. Influida por las tensiones crecientes de la Guerra Fría interamericana, las piezas se movían en el tablero con suma facilidad para impedir el avance del comunismo o sentar las bases de los cambios estructurales largamente exigidos. El concepto de revolución irradiaba el ambiente. Juan José Arévalo gobernaba Guatemala bajo esta bandera y en Costa Rica, con marcados tintes anticomunistas, el Ejército de Liberación Nacional asumió el poder en abril de ese año, finalizando así la efímera, pero cruenta, guerra civil. En los extremos del istmo - geográficamente hablando- se registraron cambios en la forma de dirigir los asuntos públicos; entretanto, las naciones del centro continuaron marchando por derroteros autoritarios. Honduras y Nicaragua vivían los efectos de regímenes que, instalados en el decenio de los treinta, habían resistido las protestas opositoras suscitadas cuatro años antes. La situación política en territorio salvadoreño tenía muchas similitudes con estas últimas naciones. El grupo cívico-militar que derrocó al general Salvador Castaneda Castro (1945-1948) por medio de un golpe de Estado, aunque prometió trasfigurar el quehacer político, observó las mismas prácticas de antaño. Un Consejo de Gobierno Revolucionario (CGR) fue instalado después del cuartelazo y tres días más tarde el recibimiento vitoreado del mayor Óscar Osorio, procedente de territorio mexicano, evidenció que detentaba el liderazgo del movimiento revolucionario.

Asumido, pues, el compromiso de la administración pública, los integrantes del gobierno publicaron una "proclama de principios y objetivos", documento en el que establecieron las normas que regirían la conducta del régimen. Entre los puntos enmarcados en el ámbito político estaban los siguientes: un sistema de gobierno democrático, libertad efectiva dentro del orden, un nuevo ordenamiento jurídico, un código electoral que torne efectiva la libertad de sufragio y, finalmente, autonomía amplia de las municipalidades (CGR, 1949a: 3). Las acciones posteriores del gobierno mostraron el incumplimiento de estos principios. El optimismo y las buenas intenciones de los primeros días se diluyeron con el transcurrir del tiempo, quedando plasmada la propaganda del régimen en los periódicos y otros medios de difusión. Y, precisamente, el objetivo del presente artículo consiste en contextualizar esta evidencia visual -imágenes y fotografías - abordando tres coyunturas queintegraron el devenir del movimiento revolucionario: la campaña presidencial de Óscar Osorio, los festejos del aniversario de la Revolución de 1948 y las campañas proselitistas orquestadas por el partido oficial. Las tres temáticas aludidas serán analizadas a partir de las reflexiones de Peter Burke sobre el uso de la imagen y la fotografía como documento histórico (Burke, 2001).

Este abordaje, que permite escapar del analfabetismo visual criticado por el autor, tiene su base material en la fototeca del Archivo General de la Nación de El Salvador (AGN) y en las diversas publicaciones del régimen resguardadas en la biblioteca de dicho recinto. Desde los años treinta se destinaron recursos públicos para cubrir los eventos de carácter político. Una instancia oficial fue creada para captar por medio del lente de sus fotógrafos las reuniones del gabinete, las visitas de los gobernantes extranjeros, la inauguración de obras públicas y las disertaciones presidenciales. El resultado de esta empresa, efectuada durante el período de los regímenes cívico-militares en El Salvador (1931-1979), son más de un millar de fotografías que integran la serie del Ministerio de Gobernación ubicada en la fototeca. Estos vestigios del pasado en el presente - como propuso llamar el historiador Gustaaf Renier a los acervos documentales - fueron reproducidos como una forma de registrar el quehacer político, que estuvo presidido por el Ministerio de Gobernación en los años estudiados. Asimismo, muchas de estas fotografías fueron publicadas en los rotativos gubernamentales y otros vehículos de propaganda oficial. De hecho, durante la administración de Óscar Osorio (19501956) es posible constatar la complementariedad entre la documentación de la labor gubernamental y el propósito de esculpir una opinión pública favorable. Al respecto, numerosas fotografías resguardadas en la fototeca aparecieron en el periódico oficial, sobre todo 
cuando las notas en las que se alardeaba del apoyo popular al régimen revolucionario requirieron una corroboración visual.

Ante el incumplimiento de los objetivos planteados por los cuadros revolucionarios y las protestas opositoras, la propaganda oficial adquirió una relevancia acentuada. La crítica mordaz de los que mostraron la imposición en los comicios, el irrespeto a los derechos políticos y la falta de autonomía municipal —como lo hizo Jorge Pinto en las páginas de su periódico El Imparcial- precisaron una respuesta. El semanario El Salvador al Día constituyó el medio para combatir los señalamientos y diseñar una imagen del escenario político a la medida del gobierno. Asimismo, durante las campañas proselitistas, el Comité de Propaganda del Partido Revolucionario de Unificación Democrática (PRUD) editó un periódico cuyo eslogan, "Hacia una nueva República libre y próspera”, encabezó el anverso de su portada. En este diario, las fotografías de Óscar Osorio como el candidato que las masas seguían, los mítines del PRUD y los desfiles militares para conmemorar un aniversario más de la Revolución abundan y se convierten en insumos para incursionar en un ámbito poco explorado de la historia política salvadoreña: la propaganda visual de un régimen que recurrió a los comicios como una forma de legitimar una selección realizada en el seno del movimiento revolucionario. Al respecto, ¿cómo fue presentada la imagen de Osorio durante la campaña presidencial de 1950? La respuesta constituye el contenido del primer apartado de este artículo.

\section{El hombre que dejó las alturas del poder para buscar a su pueblo}

Óscar Osorio tenía 38 años de edad cuando aterrizó en el aeropuerto internacional de Ilopango la mañana del 17 de diciembre de 1948. Al bajar del avión fue alzado en hombros por una multitud que esperaba ansiosa al quinto y último integrante del CGR. En junio de 1945, Osorio fue desterrado después de participar en un fallido cuartelazo contra Castaneda Castro. El honroso castigo - como fue habitual entre los militares imbuidos en disputas de poder durante la segunda mitad del siglo XX- consistió en enviarlo como agregado militar a México. Tres años más tarde, luego de observar de primera mano el régimen surgido de la Revolución de ese país, el militar graduado en la Escuela de Guerra de Turín, Italia, volvió cobijado por un movimiento cuyos protagonistas manifestaron que su acción no se trataba de un cuartelazo más, sino de una revolución. Estos cuadros castrenses —en su mayoría jóvenes y con el grado de mayor - adujeron estar dispuestos a reorientar, entre otros aspectos, la política nacional. Para concretarlo debían acabar con los vicios inveterados: imposición, fraude electoral y boicot a la oposición. Ante este desafío, en el quinto punto de su proclama contemplaron: "El establecimiento de un Código Electoral que, aprovechando las experiencias de países avanzados, y nuestra propia experiencia, que con raras excepciones demuestra la entronización del fraude, proporcione los medios para hacer efectiva la libertad de sufragio" (Cáceres, Guidos y Menjívar, 1988: 115). La prueba de fuego de la buena voluntad oficial llegó dos años después de tomar el poder, cuando organizaron la elección legislativa y presidencial prometida en los medios de comunicación.

La primera señal negativa apareció en octubre de 1949, cuando Galindo Pohl y Óscar Osorio dimitieron del CGR. Días más tarde hicieron pública su incorporación al PRUD. Galindo Pohl buscaría una curul en la Asamblea Constituyente y Osorio, el cabecilla de este movimiento, la presidencia de la República. Las protestas ante tales acciones aparecieron muy pronto, sobre todo porque pisotearon una promesa formulada por estos cuadros: abstenerse de optar en los comicios venideros a cualquier cargo de elección popular. Ante el malestar y las críticas hechas por diversos sectores, el bloque oficialista enfocó la campaña de Osorio en dos puntos: primero, interpretaron su renuncia como un acto de civismo, de necesidad ante la situación política que afrontaba el país y, segundo, presentaron a este militar como un hombre del pueblo que, debido a su extracción social y humildad palpable, atendería las exigencias más sentidas de los obreros, locatarias de mercados, campesinos y otros grupos de escasos 
recursos. En síntesis, Osorio era el militar que, al percatarse de la situación política, había dejado su alto cargo para competir por la presidencia. Este estribillo, que refleja los aspectos antes indicados, colmó las páginas del periódico del PRUD. De hecho, en uno de sus números escribieron:

Como consecuencia obligada de esa lealtad, cuando comprendieron que dentro de sus deberes está el de lograr el más efectivo y permanente respaldo a la ideología de la Revolución, el Mayor Óscar Osorio y el Dr. i. f. Reynaldo Galindo Pohl dejaron sus elevados cargos, por medio de renuncia irrevocable, para estar en igualdad de circunstancia y de posición con los ciudadanos que se entregan de lleno, sin ambiciones personalistas, a asegurar un venturoso porvenir para la Patria (Quintana, 1949: 3).

Este párrafo refleja, además, otro argumento empleado para promover la candidatura de Osorio, a saber, el venturoso porvenir de la patria estaría asegurado únicamente si los sustentadores de la ideología revolucionaria continuaban ocupando puestos de poder. En otras palabras, el mayor era el garante del proyecto económico y político echado a andar por el CGR dos años antes. En este lapso se había planificado — ante el influjo de las tesis desarrollistas - la construcción de obras de infraestructura para impulsar la actividad comercial del país, entre las que figuraba como prioridad la modernización del puerto de Acajutla. El Salvador se perfilaba hacia el derrotero del progreso auspiciado por los altos precios del grano de oro en el mercado internacional (Turcios, 1993: 113), y el movimiento revolucionario, aprovechando esta coyuntura de abundancia, hizo suyo este proyecto. Presentaron a su partido como la expresión política del desarrollo económico y, en su afán por afianzar esta vinculación, tomaron los colores de la bandera salvadoreña para colocarlos en los emblemas del PRUD. Esta operación, efectuada en México con la formación del Partido Nacional Revolucionario en 1929, impregnó la campaña proselitista de Osorio. ${ }^{2}$ En sus carteles apareció la imagen del mayor rodeada de catorce estrellas, símbolo de los departamentos del país y de los puntos de la proclama, y en el fondo el color azul y blanco como expresión de su arraigado patriotismo (ver Foto l).

Los aspectos resaltados en la campaña de Osorio y la forma otorgada a sus carteles de propaganda pueden interpretarse desde la creación de la imagen del individuo. El objetivo radica, según Burke, en "[...] mostrar al individuo como encarnación de ideas o valores. En la tradición occidental, la Antigüedad clásica ya estableció una serie de convenciones para la representación del gobernante como héroe o como personaje sobrehumano" (Burke, 2001: 88). Osorio apareció en los carteles luciendo su traje militar de gala, encarnando el orden y la disciplina garantizados por una institución autoproclamada centinela de los preceptos constitucionales. Asimismo, éste fue presentado como "[...] el personaje que bajó de las alturas del poder para unirse al pueblo, en su calidad de simple ciudadano, en la lucha por el mantenimiento de las libertades y por la solidificación del sistema democrático iniciado con la gloriosa Revolución del 14 de diciembre de 1948" (PRUD, 1949: 1). Osorio, según esta campaña, hizo un sacrificio poco usual entre los dirigentes políticos de su época: renunciar a los privilegios del poder para fundirse con el pueblo. Por esta premisa de su propaganda, las fotografías publicadas en el rotativo del PRUD mostraron a un Osorio que marchaba al frente de una multitud. El candidato, durante su visita al municipio de Berlín, Usulután, guardó su atuendo castrense para vestir un saco y portar unos lentes oscuros. Osorio era el candidato del pueblo, encarnaba el orden y el progreso nacional (ver Foto 2).

De hombre público, probo y capaz fue tildado el candidato en un manifiesto del PRUD, donde se apuntaba también "[...] su indiscutible amor patrio [por el cual], ha sabido conquistar en el seno del partido un afecto y respeto especial". Estos cumplidos hacia el líder indiscutible del movimiento revolucionario, expresados en periódicos, manifiestos y otros panfletos, integran la serie Elecciones del fondo del Ministerio de Gobernación. Estos documentos —clasificados por año en el período que atañe- guardan una riqueza 
ingente, pero, a la vez, desafíos para todo el que los consulta. Sus cajas contienen imágenes y fotografías incorporadas en rotativos y hojas volantes que tornan imperioso contextualizar esta evidencia visual. En las dos piezas estudiadas su productor puede establecerse con claridad: el Comité de Propaganda del PRUD, cuyos integrantes eran los responsables de editar el periódico del partido y la propaganda que se distribuía en los eventos proselitistas. Entretanto, la explicación de sus detalles y las razones de su reproducción radican en la coyuntura política engendrada a finales de los años cuarenta: la necesidad del movimiento revolucionario de legalizar su continuidad a través de un evento electoral. En la agenda oficial la competencia lució ausente gracias a las componendas que difuminaron cualquier opción real de triunfo opositor. Ante este panorama, la ficción democrática era necesaria, “[...] no solamente como fundamento irremplazable para la legitimidad del régimen —como explicó François Xavier Guerra en el caso del porfiriato- , sino como señal que va a mostrar a todos la coherencia y la fuerza del sistema político" (Guerra, 2012: 41).

Activadas las redes clientelares del PRUD en los departamentos del país, cooptados los diputados de la Asamblea Nacional y controlado el Consejo Central de Elecciones, el candidato oficial no hizo más que demostrar el apoyo popular del cual gozaba en su campaña proselitista. "El pueblo está con el PRUD", reza el encabezado de la fotografía en la cual Osorio es seguido por una muchedumbre que lo vitorea portando sus carteles en la campiña salvadoreña. El mayor - al atender la evidencia visual de esta fotografía y el propósito de sus propagandistas - contaba con la simpatía de la población al interior de la República, constituyendo la marcha escenificada en Usulután una prueba fehaciente. Mientras Osorio visitaba diferentes municipios, la oposición presentó peticiones para transparentar los comicios. Exigió concretar primero la elección de la Constituyente y luego votar por quien ocuparía la Primera Magistratura. Sin embargo, su moción fue desoída y la elección de autoridades supremas se realizó en una misma jornada. Durante tres días los ciudadanos asistieron a votar por los partidos en contienda: el PRUD y el Partido Acción Renovadora (PAR), cuyo candidato presidencial era el coronel José Asensio Menéndez, antiguo opositor del régimen presidido por Maximiliano Hernández Martínez (1931-1944). El resultado de la votación favoreció el oficialismo, situación que provocó protestas airadas.

Según las autoridades del PAR, la votación había sido coercitiva y fraudulenta, lo cual era evidente en las pequeñas poblaciones, donde muchos caseríos aparecieron con un gran número de votantes. Los reclamos de estos cuadros cayeron en saco roto. El ente responsable de presidir las elecciones validó los datos, lo que permitió que los revolucionarios capitalizaran dos objetivos: "[...] en primer lugar, dominar la Asamblea Constituyente y ganar las votaciones presidenciales; en segundo lugar, hacerlo frente a contendientes de reconocida trayectoria opositora" (Turcios, 1993: 69). El 27 de marzo de 1950, Osorio recibió de manos del titular del Consejo Central de Elecciones la credencial como presidente electo. "Espléndida lección de civismo dio el pueblo salvadoreño durante los pasados comicios, ofreciendo, además, un magnífico ejemplo de orden y elevada cultura", manifestaron en el semanario El Salvador al Día. Asimismo, aprovecharon este espacio para remitir un mensaje a los opositores: “[...] el fallo del pueblo ya está dado. Acatarlo es un deber de indiscutible patriotismo" (CGR, 1950: 1).

\section{Los festejos conmemorativos de la Revolución}

La Revolución de 1948 fue un movimiento de derecha que transitó por derroteros progresistas, encarando a la oligarquía terrateniente en su intento de modernizar la economía, y coercitivos al sabotear cualquier expresión político partidista contraria a sus designios. El grupo en el poder enfrentó divisiones internas, coordinó una vasta red clientelar para adjudicarse cuanta elección organizaran y promulgó leyes en las que las organizaciones comunistas fueron proscritas. Mientras establecían el argumento del orden constitucional para perseguir, apresar y desterrar a sus rivales políticos, crearon entidades que buscaron promover el bienestar público como el Instituto 
Regulador de Alimentos, el Instituto de Vivienda Urbana y el Instituto Salvadoreño del Seguro Social, entre otras. Sustentado por el apogeo cafetalero de los años cincuenta, el movimiento revolucionario puede definirse como un régimen autoritario anticomunista con pretensiones desarrollistas. En síntesis, forjaron un Estado intervencionista en el ámbito económico cuyas arcas fueron empleadas para conmemorar su arribo al poder. Algunos monumentos develados en estos eventos aún integran el paisaje capitalino; no obstante, sobre sus festejos se ha escrito poco.

El objetivo del régimen prudista de establecer un antes y un después de su movimiento en el imaginario colectivo tuvo en las celebraciones de cada 14 de diciembre un vector esencial. Los desfiles militares, bandas musicales extranjeras, torneos de fútbol internacional, alboradas y conciertos de marimba en cada municipio perseguían metas bastante definidas: mostrar a sus oponentes la popularidad de su movimiento y reafirmar que gozaban del apoyo indiscutido del ejército. De hecho, el 6 de diciembre de 1950 dicho festejo fue instituido mediante un decreto legislativo en cuyo primer artículo se estipulaba: "Declárese DÍA DE FIESTA NACIONAL con asueto, el 14 de diciembre de cada año. En consecuencia, el Pabellón Nacional deberá izarse en todos los Cuerpos Militares y edificios públicos del país, con los honores de ordenanza" (Leistenschneider, 1980: 679). En adelante, y durante una década, los salvadoreños presenciaron la coordinación y el denuedo de los empleados públicos por conmemorar un aniversario más de la Revolución. Examinar estos eventos, en los que las fotografías ocuparon un lugar central — como mostraré más adelante-, posibilita inspeccionar una faceta desconocida del régimen prudista: su afán por exhibir la vitalidad de su movimiento político. El 20 de diciembre de 1950, el alcalde de La Libertad detalló al ministro de Gobernación, teniente coronel José María Lemus, la forma en que fue celebrado el segundo aniversario de la Revolución:

Me permito el alto honor de informar a usted, que el día 14 de diciembre, segundo glorioso aniversario de la Revolución, fue celebrado aquí, del modo siguiente: A las 4 de la madrugada, alegre alborada amenizada con marimba llevada en un camión, recorriendo toda la población, quemándose bombas y petardos en todo el trayecto.

De las 9 de la noche a las 2 de la madrugada, en los salones de la Alcaldía, gran baile popular amenizado con marimba. Este mismo día hubo quema de pólvora, luces de bengala, castillos, cohetes, toretes, etc., desde las 9 de la noche en adelante, frente al parque central. A estos actos concurrió numeroso público y el festival se hizo por contribución del suscrito, de la Directiva del PRUD y personas de buena voluntad. ${ }^{3}$

Si la pólvora y los bailes caracterizaron el aniversario de la Revolución en la entonces villa de La Libertad, el régimen no escatimó esfuerzo alguno por engalanar aún más dicha celebración en la capital (ver Foto 3). En la Foto 3 puede observarse el desfile militar con cientos de soldados pasando justo frente al Palacio Nacional, ubicado en el centro de San Salvador. Este cuadro nos transporta al tercer aniversario de la Revolución, fecha en la cual el régimen afinaba su engranaje electoral para renovar el pleno legislativo. Luego del triunfo arrollador de Osorio en los comicios de 1950, en los cuales su partido obtuvo también la mayoría de curules en la Asamblea Constituyente, tocaba corroborar el empuje del partido oficial sin la presencia de su líder en la contienda. Ciertamente, como se exhibe en los archivos del Ministerio del Interior, la red clientelar y de espionaje aunaba esfuerzos para impedir la presencia opositora en los cantones del país; sin embargo, el régimen necesitó un baño de multitudes que desvirtuara los señalamientos venideros. Así, restando pocas semanas para instaurar las mesas electorales, las calles del centro capitalino lucieron abarrotadas de espectadores. Osorio y su gabinete, apostado desde un balcón del Palacio Nacional, saludó al público y éste constató de primera mano la vitalidad del régimen.

Las imágenes, en este sentido, tienen un testimonio que ofrecer acerca de la organización y puesta en escena de los acontecimientos (Burke, 2001: 17). En el caso particular del régimen prudista permiten subrayar un 
elemento que pregonaron a los cuatro vientos, a saber, la unión entre el gobierno y el ejército. Por ello, los desfiles militares resultaron propicios. Asombraron a propios y extraños por su despliegue y, ante la disciplina marcial exhibida, mostraron el respaldo de la institución castrense al movimiento revolucionario. De hecho, durante el primer aniversario de la Revolución, el bullicio habitual de los vendedores en las avenidas del centro capitalino fue acallado por los motores de los tanques de guerra, cuyos pilotos rindieron un saludo marcial al presidente (ver Foto 4). "Todos los ciudadanos, sin distinción de clases ni de categorías — se indicó en el rotativo oficial- celebraron con gran júbilo el primer aniversario de la gloriosa Revolución que restauró la vigencia de las instituciones democráticas" (CGR, 1949b: 1). Un año más tarde, el mismo Osorio señaló la fórmula exitosa de su movimiento:

\section{Cumple ahora dos años la dura tarea de estructurar una revolución, ahora más que entonces nos sentimos orgullosos de que Pueblo y Ejército hayan unido su fe para la realización de la gran obra nacional, cuyo objetivo principal es el bien común. Pueblo y Ejército unidos, esa es la fórmula única; es la unidad perfecta que necesita la Revolución Salvadoreña para la realización de sus objetivos (Secretaría de Información de la Presidencia, 1950: 1).}

Nos hallamos, pues, ante la versión oficial de los festejos de la Revolución. Se trata de imágenes que fueron publicadas para exhibir multitudes, evidenciar la vitalidad del movimiento político y desvirtuar los señalamientos opositores. La ruta seguida para interpretar estas imágenes atiende la indicación de Burke, quien aconsejó “[...] a todo el que intente utilizar el testimonio de una imagen, que empiece por estudiar el objeto que con ella persigue el autor" (Burke, 2001: 22). La Revolución experimentó su mejor momento en los albores de los años cincuenta: la dirigencia lucía consolidada en el poder, las obras de infraestructura constataban el empuje gubernamental y las arcas estatales marcaban saldos positivos. El régimen, conforme los precios del café en el mercado mundial se dispararon, pasó a administrar la abundancia, ${ }^{4}$ a tal grado que, para festejar el tercer aniversario de la Revolución, organizaron una cuadrangular de fútbol en la que el invitado de honor fue el equipo subcampeón argentino, el Banfield, que saltó al terreno de juego del Estadio Nacional en diciembre de 1951 portando la bandera salvadoreña (ver Foto 5). La predilección del régimen por los eventos multitudinarios era evidente. Miles de aficionados colmaron las gradas del estadio y la crónica de la época — portadora del célebre dicho "jugamos como nunca, pero perdimos como siempre"permite transportarnos a aquella tarde decembrina:

En los anales del historial deportivo nacional ningún evento había reunido tanto público como sucedió ayer en el Estadio, con la doble programación balompédica internacional brindada a la fanaticada como número cumbre de los festejos conmemorativos del Tercer Aniversario de la Revolución de diciembre de 1948. Un verdadero mar humano. Algo asombroso y espectacular. [...] El triunfo fue para la visita $-\mathrm{y}$ así tenía que suceder - pues, iquién puede contra estos artífices del balompié? Pero se jugó como se deseaba y aunque se perdió por dos goles a uno, la multitud quedó satisfecha de la labor rendida por la representación nacional (Rodríguez, 1951: 1-4).

Esparcimiento familiar y disciplina marcial en el desfile caracterizaron el tercer aniversario de la gesta revolucionaria. Su conmemoración era una fiesta nacional orquestada por un régimen que, según la propaganda oficial, había cambiado el destino de esta nación centroamericana. Por ello, “[...] tanto la selección de los acontecimientos dignos de conmemoración como la forma en que son presentados, constituye un testimonio del carácter del régimen que los produjo" (Burke, 2001: 183). Ante esta premisa es factible sostener que el prudismo, por medio de estos festejos, pretendió erigirse en un hito de la historia política salvadoreña. Durante el siglo pasado no volvió a erigirse otro régimen con estos afanes propagandísticos, aunque varios emularon su forma de dirigir el ámbito político. A partir de 1952 — retornando al análisis del prudismo- la 
participación opositora desapareció de la Asamblea Nacional. Los comicios municipales y legislativos fueron celebrados cada dos años, pero las medidas para frenar su accionar impidieron cualquier triunfo opositor. En la fototeca del Archivo General de la Nación se resguardan únicamente fotografías del proselitismo oficial, expresión fehaciente del unipartidismo en la administración pública que caracterizó el decenio de los cincuenta en territorio salvadoreño.

\section{Dos estampas del proselitismo oficial}

Cientos de fotografías conforman la subserie elecciones de la fototeca del Archivo General de la Nación. En enero de 2013 inició el proceso de descripción archivística contando con un problema que se torna desafío: las fotografías se adhirieron originalmente en carpetas con pocos datos sobre el lugar donde fueron tomadas, los personajes que aparecen y el evento captado por el fotógrafo a través de su lente. Sin embargo, el trabajo del encargado de la fototeca, Pedro García, basándose en las escasas referencias, los rostros, eventos y sitios reconocibles, así como la guía de estudiosos del período, ha subsanado en buena medida las falencias señaladas. El resultado de este esfuerzo es la descripción de una serie de fotografías que permiten apreciar el proselitismo del PRUD, los eventos electorales y la coordinación fraguada desde las instancias gubernamentales para realizar dichas jornadas. La primera fotografía elegida para este apartado exhibe una de las estrategias de propaganda del PRUD y la segunda la coordinación desarrollada en el ministerio rector de la vida política. Contextualizarlas representa el paso siguiente (ver Fotos 6 y 7 ).

El PRUD fue creado en agosto de 1949. La Junta Directiva Central quedó integrada por destacados intelectuales y algunos terratenientes. Atilio García Prieto, José María Peralta, José Kuri y Humberto Romero Albergue, entre otros, estamparon su firma para constituir el partido que promovería los principios del movimiento revolucionario. Delinearon el plan de acción de su organización y aprovecharon para darlo a conocer durante la campaña presidencial de
1950. Entre sus puntos definieron la ideología de su partido, prometieron eliminar cualquier práctica fraudulenta y estipularon los vectores para adjudicarse adeptos: "El partido usará la propaganda a través de manifestaciones, mítines, periódicos, folletos, hojas sueltas, radiodifusoras y otros medios lícitos". ${ }^{5}$ Toda esta actividad - cuyos vestigios constituyen los insumos de este artículo- estuvo coordinada por diversas entidades partidarias conformadas en los departamentos del país. En la cúspide de la pirámide se encontraba la convención general, el comité ejecutivo y órganos superiores, mientras la plataforma estuvo constituida por la directiva general, regional y distrital, así como por los núcleos básicos de organización. Además, el PRUD fue dotado en sus comienzos de una organización “[...] de carácter semicorporativista, a través de diversas ramas destinadas a representar sectores de la sociedad" (Cáceres, Guidos y Menjívar, 1988: 101). Bajo este esquema surgió un sector estudiantil, profesional y magisterial.

El objetivo estipulado en el plan de acción de los prudistas y la estructura organizativa citada sirven para contextualizar el evento captado en la fotografía (ver Foto 6). El lugar y la fecha del mitin son desconocidos, lamentablemente. Sin embargo, puede apreciarse la pancarta con la bandera del PRUD arriba del podio y en ésta la invitación a marcar dicho emblema en la próxima jornada electoral. Asimismo, aparece en la fotografía un detalle muy importante. Tras el orador de turno fue colocado un cuadro con dos brazos sosteniendo una antorcha. La flama representó a la Revolución, el brazo con la manga del uniforme militar al ejército y el segundo totalmente desnudo al pueblo salvadoreño. La unión entre la institución castrense y la civilidad constituyó - como sostuvo Osorio en el discurso citado párrafos antes - la fórmula exitosa del movimiento revolucionario y este principio impregnó sus campañas. Una opinión pública favorable al ejército intentó edificarse en los años cincuenta, contrarrestando la imagen formada ante la imposición y la corruptela de dicha institución.

Los mítines y otras medidas propagandísticas representaron, por otro lado, la faz visible del partido 
oficial. De hecho, quien contempla las fotografías de su proselitismo sin ningún tipo de información puede atribuir a la eficacia de sus campañas la obtención de triunfos altisonantes en dos comicios presidenciales y cinco municipales y legislativos durante los años cincuenta. No obstante, esta racha de victorias no respondió mayoritariamente a la elocuencia de sus oradores o al contundente mensaje plasmado en sus hojas volantes y periódicos. Detrás de estas acciones ejerció su tarea de sabotaje opositor una red de espionaje y coerción comandada por funcionarios públicos. Un ejemplo de lo anterior aparece en un informe del gobernador de Cabañas, Benjamín Simó Leiva, remitido a su superior. Entre sus líneas puede leerse:

Tengo la honra de dirigirme a usted para informarle que el jueves próximo pasado regresé de la gira oficial por los pueblos del Distrito de Ilobasco y San Isidro de esta jurisdicción, habiendo podido comprobar que en la actualidad solamente el partido Revolucionario de Unificación Democrática está desarrollando actividades políticas en este Departamento. Los Alcaldes están dando cumplimiento a lo ordenado de conformidad con las instrucciones recibidas de esa Superioridad, están elaborando las listas de las personas de ambos sexos mayores de dieciocho años para después hacer su inscripción en los libros de registro de electores, tarea a la que prestan su colaboración los Comandantes Locales, Delegaciones de la Directiva Departamental del PRUD y últimamente los profesores rurales, pues el señor Delegado Escolar de este Circuito don Rafael Quintanilla ya reorganizó las Directivas de los pueblos y cantones del PRUD magisterial, de manera pues que hasta estos momentos la situación política en este Departamento es favorable al Gobierno. ${ }^{6}$

Los miembros de la red de espionaje y coacción incluidos por Simó Leiva en su informe traslucen la estructura del partido oficial. Su objetivo no era otro que defenestrar por completo cualquier proselitismo opositor de los cantones y caseríos. Usando la fuerza y la amenaza, pero también el descrédito hacia los partidos que se organizaban y el temor de la población ante la pérdida de las dádivas otorgadas por el régimen revolucionario. "iAlerta compañeros trabajadores!", escribieron en una hoja volante, "El nuevo partido político que ha salido a la luz pública bajo el nombre de PARTIDO DEMÓCRATA, es un bloque patronal formado para luchar activamente contra las conquistas laborales consignadas en la Constitución de 1950". 7 Y finalizaron su volante con esta advertencia: "iAy de nosotros si por colaboración o por indiferencia nos prestamos a que estos señores lleven sus propias planillas de diputados a la próxima Asamblea Legislativa!". Ahora bien, iquién era el encargado de dirigir y coordinar estas acciones? La respuesta conduce directamente al Palacio Nacional, en cuyas instalaciones se encontraba la oficina del ministro de Gobernación, protagonista de la última fotografía de este artículo (ver Foto 7).

El teniente coronel José María Lemus recibía a sus invitados detrás del escritorio, en cuya superficie se distinguen algunos documentos y un juego de plumas dispuestas para estampar su firma. La descripción de la fotografía no contiene una fecha exacta de su toma, pero se infiere debido al período en el cual fue clasificada originalmente, el gobierno de Osorio (1950-1956), que corresponde a una reunión del ministro de Gobernación con miembros del partido oficial. En septiembre de 1950, Lemus, sin estar inscrito en la nómina del PRUD, ratificó la importante labor de presidir el ministerio rector del entramado político partidista. Su continuidad no radicó, por consiguiente, en cuotas de poder cobradas por los sectores partidarios, sino en su encomiable desempeño dentro de la institución castrense. Lemus fue un intelectual distinguido que, durante el gobierno provisional del general Andrés Menéndez (1944), blandió su pluma para defender al ejército y justificar su intervención en la vida pública salvadoreña. Disciplina, confidencialidad y lealtad eran los atributos indispensables de la persona que asumiera la conducción de la cartera de Estado donde se coordinaban, además de los comicios, los arreglos previos que allanaban el camino de las conquistas prudistas. Su titular, escrito en otras palabras, no 
respondió únicamente a los intereses nacionales, sino también a los objetivos del partido de gobierno.

Lemus, quien después de su tránsito por el gabinete de Osorio se convirtió en el segundo presidente del movimiento revolucionario, nació el 21 de julio de 1911, en el puerto de La Unión, como establecieron las autoridades salvadoreñas en 1956. La controversia por su nacionalidad estalló durante la campaña proselitista que lo condujo al ejecutivo, cuando muchos adujeron que su partida de nacimiento se encontraba en Honduras. Ante las pruebas que lo invalidaban como candidato presidencial, el régimen se apresuró a arreglar el problema. La acusación era un simple malentendido: Lemus vio la luz en el barrio de Honduras, ubicado en una localidad fronteriza, y este nombre provocó la suspicacia de sus oponentes. Sus padres eran maestros de escuela y toda la instrucción recibida en casa le sirvió para ingresar como escribiente en la Guardia Nacional a la edad de quince años. El trabajo en esta institución fue forjando su gusto por la vida castrense y el 1 de marzo de 1930 fue admitido como caballero cadete (Ventocilla, 1956: 35-42).

Luego de sus estudios en la Escuela Militar, ocupó puestos de mando en los cuerpos de seguridad durante el martinato. Su desempeño y su deleite por las letras le valieron para ser enviado al extranjero; retornó de sus estudios en Estados Unidos a mediados de los años cuarenta y posteriormente encabezó diversas misiones internacionales. Para finalizar, en 1948, cuando Castaneda Castro intentó reelegirse y sobrevino el cuartelazo, Lemus se avocó a la Guardia Nacional para afianzar la lealtad de este cuerpo hacia los sublevados. En su relato de este acontecimiento hizo hincapié en la unión entre el pueblo y el ejército, exhortación que, como he mostrado en las páginas de este artículo, constituyó un argumento recurrente entre los dirigentes revolucionarios. El ejército en este discurso emanaba del pueblo para defender las garantías constitucionales.

Luchábamos en ese período de adaptación, en el que indudablemente se encuentra la verdadera raíz del movimiento libertario de 1948, en primer lugar por romper la tradicional separación entre el pueblo y el ejército, sagazmente fomentada por quienes buscaban el medro personal y la constitución de un estado de cosas insostenibles en el mantenimiento de esas diferencias; y en segundo lugar luchábamos por robustecer las ideas democráticas dentro del propio ejército, buscando cómo hacer posible que éste sobreviviera, para garantía del propio pueblo (Ventocilla, 1956: 109).

Con el transcurrir de los años, Lemus se convirtió en un hombre clave en el engranaje político del régimen. ¿Había otro cuadro más apto para encabezar el segundo gobierno revolucionario? ¿Quién poseía mayor habilidad para dirigir los mecanismos patentes y subrepticios que gestaban los triunfos del PRUD que este oficial? A principios de 1956 la primera pregunta fue respondida de manera positiva por sectores del oficialismo. De hecho, esto provocó que algunos elementos civiles y castrenses optaran por conformar sus partidos políticos para lanzarse al ruedo electoral. El régimen, sin embargo, defendió la candidatura de Lemus a toda costa. La respuesta negativa de la segunda pregunta adquirió un peso decisivo en esta coyuntura.

En efecto, Lemus movió las palancas de un ministerio poderoso por más de un sexenio. Apostado en su despacho - como se observa en la fotografía-, este oficial ejerció las siguientes funciones: velar por la conservación del orden público, atender el movimiento migratorio, vigilar los procesos electorales, garantizar la libertad de prensa, atender el Gobierno nacional mediante las catorce gobernaciones departamentales, manejar la Tesorería General de Fondos Específicos Municipales, mantener los servicios de la Dirección General de Telecomunicaciones, dirigir la Imprenta Nacional, el Diario Oficial, la Comisión de Censura y Espectáculos Públicos y, por si fuera poco, la Junta de Química y Farmacia. Ahora bien, si a este listado extenso se le agrega el papel que el ministro de Gobernación desempeñaba en el partido oficial--avalando las nóminas de los ediles y diputados para los comicios y dirimiendo los conflictos desencadenados ante este proceso-, puede explicarse por qué la mayoría de militares que ocuparon el cargo se convirtieron 
posteriormente en presidentes de la República. Apuntado todo lo anterior, es posible ubicar la fotografía donde aparece Lemus con los correligionarios del PRUD en un contexto determinado. Sin duda, la identificación de los cuadros sentados a su alrededor precisa una indagación ulterior; no obstante, la especificación de las funciones del ministro de Gobernación fuera y dentro del partido oficial brindan pistas sugerentes para acometerla.

\section{Consideraciones finales}

En las páginas anteriores examiné algunas muestras de la propaganda visual del PRUD durante la campaña proselitista de Osorio, tres fotografías de las conmemoraciones de la Revolución de 1948 y dos estampas del proselitismo oficial con miras a los comicios municipales y legislativos. Por medio de estas piezas se mostraron algunos pasajes de la historia política salvadoreña de los años cincuenta. La incursión en esta faceta muy poco estudiada del régimen revolucionario torna conveniente una breve reflexión sobre el uso de la fotografía como documento histórico.

En efecto, lo primero que debe señalarse —acudiendo nuevamente a Peter Burke - es que: "A cierto nivel, las imágenes son una fuente poco fiable, un espejo deformante. Pero compensan esa desventaja proporcionando buenos testimonios a otro nivel, de modo que el historiador puede convertir ese defecto en virtud" (Burke, 2001: 38). La cita anterior permite formular una pregunta: ipor qué las fotografías resultan poco fiables y, colocándose en una postura escéptica, se consideran un espejo deformante de la realidad? Para dar una respuesta es preciso comenzar por criticar - 0 acaso demoler - el dicho popular según el cual una imagen vale más que mil palabras. Esta afirmación, aunque pondera la importancia de estas piezas, resulta totalmente falaz. Una imagen precisa siempre de las palabras para contextualizarse. Si obviamos este método - que consiste en ubicar la fotografía en el determinado escenario político, económico, social o cultural donde se produjo- corremos el riesgo de interpretarla de forma errónea o, en el peor de los casos, sencillamente guardar silencio. Por esta razón, el desafío primordial del investigador consiste en añadir y explicar aquello que luce ausente en la fotografía observada.

Una vez efectuado este procedimiento podemos disfrutar de y aprovechar las virtudes y los testimonios que contienen las fotografías. En el caso del movimiento revolucionario - como se mostró en líneas anterioresesta metodología posibilita plantear tesis interpretativas novedosas. Una de éstas concierne a las estrategias utilizadas por el régimen para forjar una opinión pública favorable y ganar adeptos en sus campañas electorales. Ante la crítica opositora que evidenciaba el incumplimiento de sus promesas iniciales, el prudismo fabricó una realidad adyacente. Osorio no pisoteó su promesa de no optar por ningún cargo público en 1950, sino que descendió de las alturas del poder para buscar a su pueblo. La población acuerpaba al movimiento revolucionario, afirmación que se constataba cuando tupía las calles para presenciar el desfile o festejar al ritmo de marimba y pólvora cada 14 de diciembre. El partido oficial organizaba mítines en los cuales colocaron cuadros que simbolizaban la unión entre el ejército y el pueblo salvadoreño. Empero, mientras esta imagen era publicitada en afiches, semanarios y otros medios, la oposición optaba por abstenerse de los eventos electorales, como fue el caso del PAR en 1952, al considerar "[...] que lanzarse a tal contienda bajo procedimientos antidemocráticos equivale a defraudar en sus más caras aspiraciones al pueblo salvadoreño".

Ciertamente, todo régimen político contempla el objetivo de dar a conocer sus logros y moldear así una imagen favorable de los ciudadanos. Sin embargo, esta meta tuvo en el prudismo una característica peculiar, a saber, buscaron instituir su movimiento como un hito en la historia salvadoreña y para hacerlo contaron con la bonanza de las arcas públicas. Diversión y un baño de multitudes fueron las estrategias para promover su movimiento. "Se diría que sólo atizando el fanatismo colectivo - aseveró Yo el Supremo de Augusto Roa Bastos - pueden esconderse las miserias que lo entrampan" (Roa, 2017: 384-385). Y el caso del régimen prudista ejemplifica con creces la afirmación anterior. En síntesis, la propaganda oficial de estos años 
posibilitar apuntalar otra clave explicativa sobre la continuidad de los regímenes cívico-militares durante la centuria pasada en El Salvador, alejada de la coerción y centrada en un aspecto que los historiadores hasta la fecha han indagado poco: la propaganda oficialista y su impacto en la formación de la opinión pública.

\section{Notas}

${ }^{1}$ El Consejo de Gobierno estuvo integrado por Reynaldo Galindo Pohl y Humberto Costa, civiles; provenientes de las filas del ejército, el mayor Óscar Bolaños, el teniente coronel Manuel de Jesús Córdova y el mayor Óscar Osorio. Este último nació en la ciudad de Sonsonate el 14 de diciembre de 1910 y falleció el 6 de marzo de 1969 en Houston, Estados Unidos. "Hizo sus estudios superiores en varias academias nacionales y extranjeras, pero principalmente 3 años en la Escuela de Guerra de Turín, Italia; de donde regresó al país en octubre de 1943" (Leistenschneider, 1980: 9).

${ }^{2}$ Osorio había residido en México como agregado militar y en el sistema político de esta nación se inspiró - según Erik Ching y Héctor Lindo- para implementar la combinación de populismo y fuerte autoridad central del gobierno. Empero: "Los intentos de Osorio y sus colegas revolucionarios de copiar el modelo mexicano revelan las enormes diferencias que separan a las dos naciones. Aparte de las obvias características de tamaño geográfico y población, el gobierno mexicano estaba dirigido por un partido político que había surgido directamente de la revolución mexicana, un levantamiento social masivo que dio al traste con el viejo orden liberal. Por el contrario, las elites terratenientes en El Salvador nunca tuvieron que enfrentarse a semejante reto. Por lo tanto, independientemente de lo que Osorio u otros reformadores en El Salvador hayan querido lograr, tuvieron que negociar con las poderosas elites terratenientes" (Lindo y Ching, 2017: 87).

3 Alcalde de La Libertad informa cómo fue celebrado el 14 de diciembre, $2^{\circ}$ glorioso aniversario de la Revolución. 20 de diciembre de 1950. Fondo Ministerio de Gobernación, serie política, caja 10, exp. 40. Archivo General de la Nación, El Salvador.
${ }^{4}$ El precio del grano de oro incrementó vertiginosamente durante la administración de Óscar Osorio (1950-1956). En 1948 el quintal costaba 73.38 colones. A partir de ese año el aumento fue considerable, llegando a su precio tope en 1954, cuando se cotizó en 170.06 colones por quintal (Cáceres, Guidos y Menjívar, 1988: 30-31).

5 Plan de Acción del Partido Revolucionario de Unificación Democrática. 1949. Ministerio del Interior, serie política, caja 13, carpeta 10. Archivo General de la Nación, El Salvador.

${ }^{6}$ Informe del gobernador de Cabañas dirigido al ministro del Interior. 1952. Ministerio del Interior/Gobernación, serie política, caja 13, carpeta 3. Archivo General de la Nación, El Salvador.

7 "iAlerta compañeros trabajadores!" [hoja volante firmada por el Comité Pro-Derechos Laborales], 1952. Ministerio del Interior/Gobernación, serie política, caja 13, carpeta 3. Archivo General de la Nación, El Salvador.

${ }^{8}$ Manifiesto del Partido Acción Renovadora al pueblo salvadoreño [hoja volante]. 8 de abril de 1952. Ministerio del Interior/Gobernación, serie política, caja 15, carpeta 4. Archivo General de la Nación, El Salvador.

\section{Referencias}

Burke, Peter (2001). Visto y no visto. El uso de la imagen como documento histórico. Barcelona: Crítica.

Cáceres Prendes, Jorge, Rafael Guidos Béjar y Rafael Menjívar Ochoa (1988). El Salvador: una historia sin lecciones. Costa Rica: FLACSO.

CGR (Consejo de Gobierno Revolucionario) (1949a). "Principios y objetivos que norman la conducta del régimen instaurado a raíz de la Revolución del 14 de diciembre". En El Salvador al Día. Correo Semanal, 17 de diciembre, p. 3.

CGR (Consejo de Gobierno Revolucionario) (1949b). "Con inmenso júbilo celebró todo el pueblo salvadoreño el primer aniversario de la gloriosa Revolución del 14 de diciembre de 1948". En El Salvador al Día, Correo Semanal, 24 de diciembre, p. 1 .

CGR (Consejo de Gobierno Revolucionario) (1950). "Espléndida lección de civismo dio el pueblo 
salvadoreño durante los pasados comicios, ofreciendo, además, un magnífico ejemplo de orden y elevada cultura”. En El Salvador al Día, Correo Semanal, 29 de abril, p. 1.

Guerra, François-Xavier (2012). México: del antiguo Régimen a la Revolución. México: Fondo de Cultura Económica.

Leistenschneider, María (1980). Teniente coronel Óscar Osorio y su administración. El Salvador: Imprenta Nacional.

Lindo Fuentes, Héctor y Erik Ching (2017). Modernización, autoritarismo y guerra fría. La reforma educativa de 1968 en El Salvador. El Salvador: UCA Editores.

PRUD(1949). “EldepartamentodelaUnión seidentificacon el prudismo". En PRUD. Órgano del Partido Revolucionario de Unificación Democrática, 8 de diciembre, p. 1 .
Quintana, J. (1949). "Elevado ejemplo de civismo". En PRUD. Órgano del Partido Revolucionario de Unificación Democrática, 1 de diciembre, p. 3.

Roa Bastos, Augusto (2017). Yoel Supremo. Madrid: Cátedra. Rodríguez, E. (1951). "Más de 40,000 personas vieron al Banfield". En El Diario de Hoy, 15 de diciembre, pp. 1-4. Secretaría de Información de la Presidencia (1950). "Mensaje del presidente de la República, Teniente Coronel Óscar Osorio al Pueblo Salvadoreño al Conmemorarse el Segundo Aniversario de la Revolución". En El Salvador al Día, Correo Semanal, 16 de diciembre, p. 1.

Turcios, Roberto (1993). Autoritarismo y modernización. El Salvador 1950-1960. El Salvador: Editorial Tendencias.

Ventocilla, Eleodoro (1956). Lemus y la Revolución salvadoreña. México: Ediciones Latinoamérica. 
Foto 1. Cartel de la campaña proselitista de Óscar Osorio. 1950

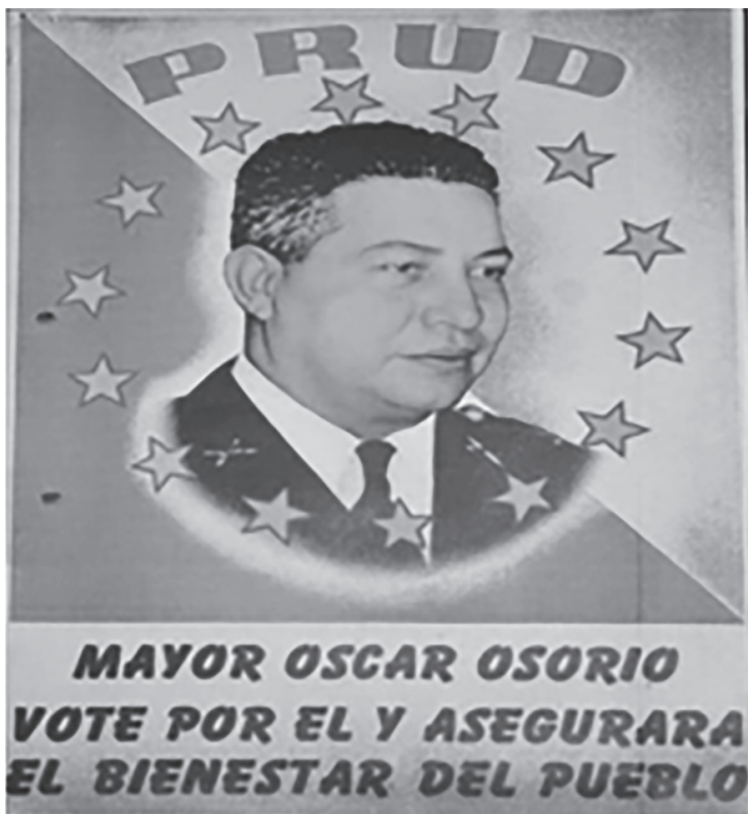

Fuente: Archivo General de la Nación. Fondo del Ministerio de Gobernación. El Salvador.
Foto 2. Campaña proselitista de Óscar Osorio

Movilización de las Fuerzas del PRUD Para Llevar el Alfabeto Hasta el Ultimo Rincón Salvadoreño Nuestro Pueblo Necenita In Asistencin de la Cultura y del Inatrumento Liberador de la Luz

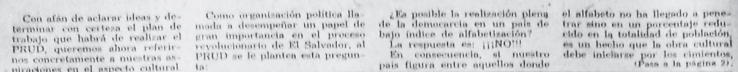
Decidido a Cambiar de Manera Radical la Grave Situación del Pueblo Está el PRUD

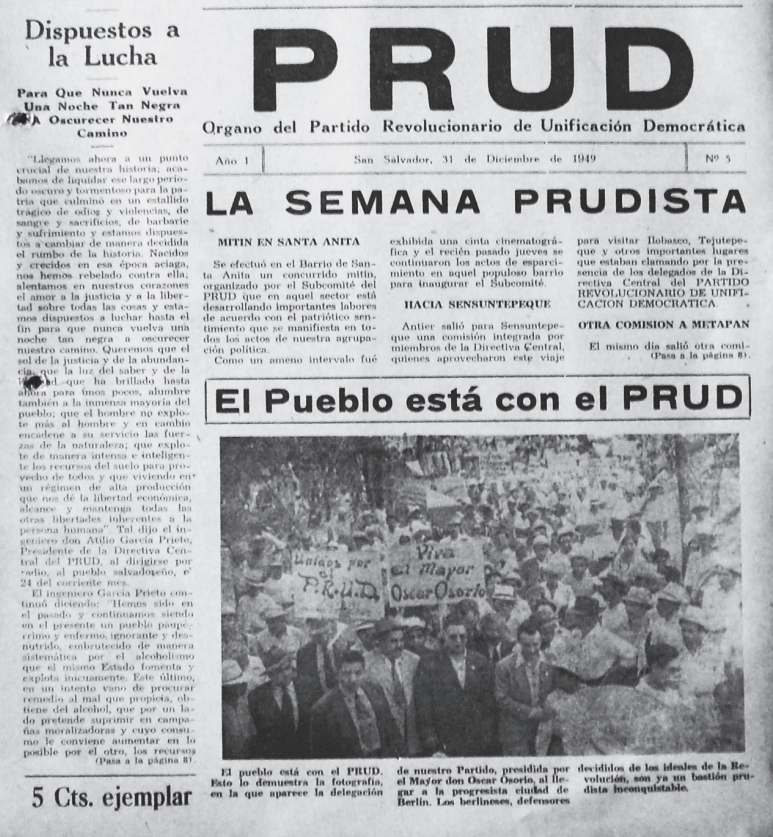

Fuente: PRUD. Órgano del Partido Revolucionario de Unificación Democrática. San Salvador, 31 de diciembre de 1949. 
Foto 3. Tercer aniversario de la Revolución de 1948

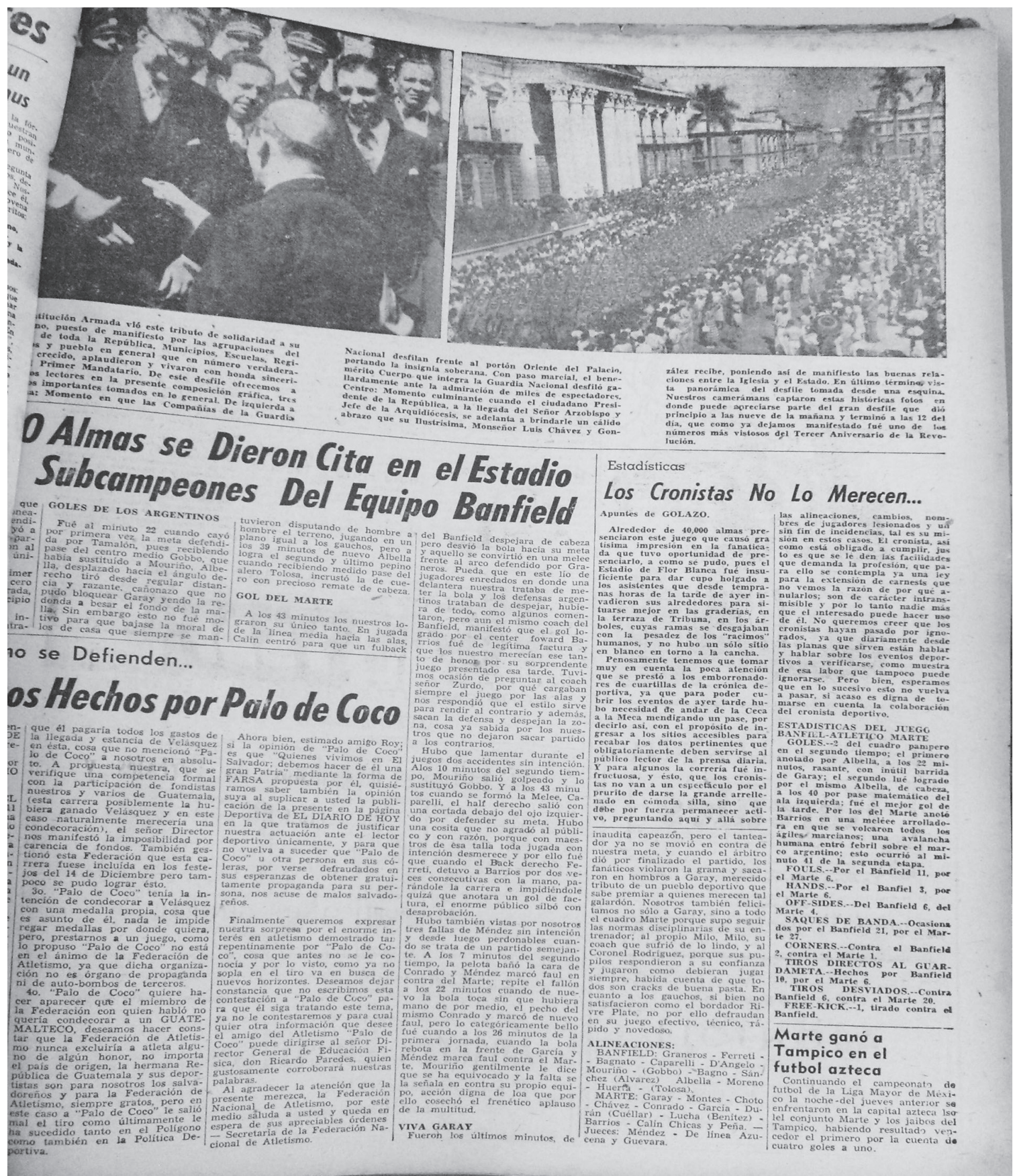

Fuente: El Diario de Hoy. Diciembre de 1951. 
Foto 4. Primer aniversario de la Revolución de 1948

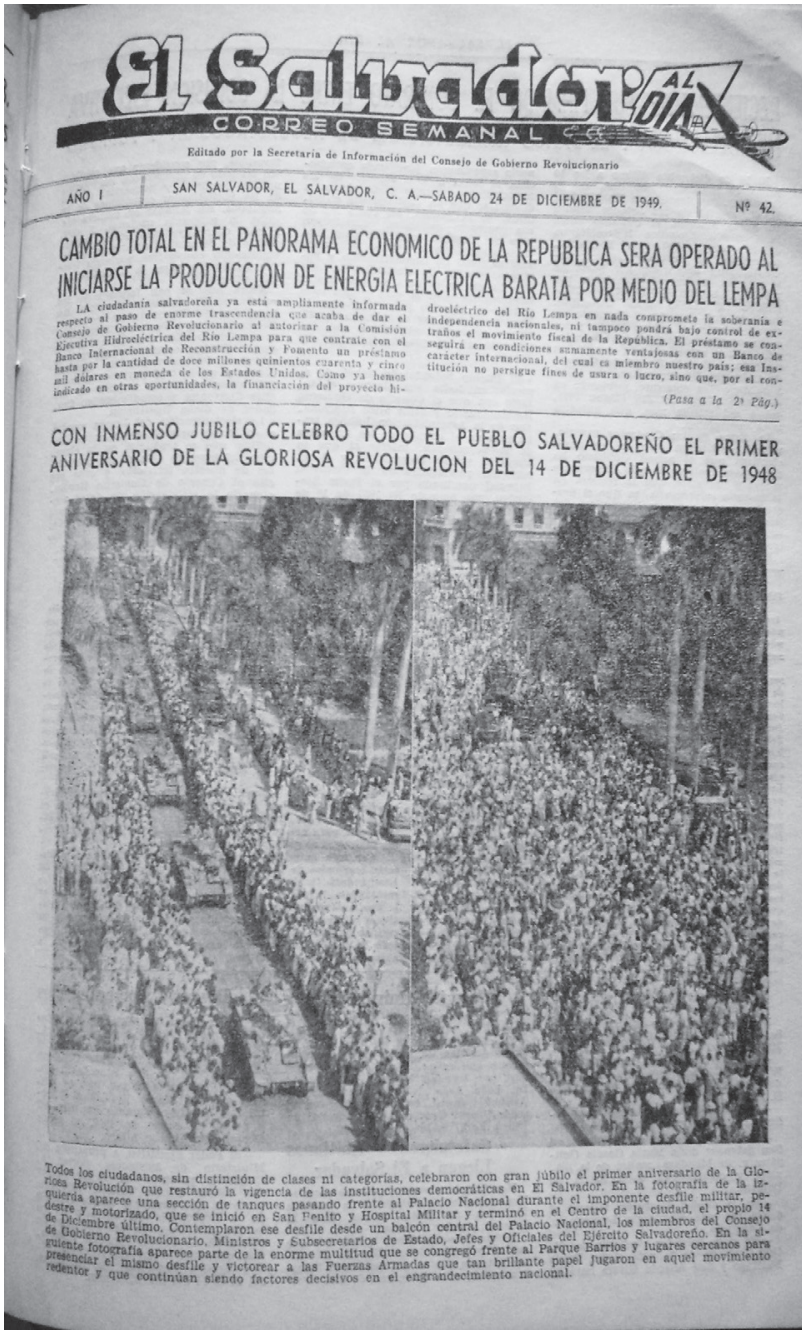

Fuente: El Salvador Al día, sábado 24 de diciembre de 1949.
Foto 5. Jugadores del Banfield visitan El Salvador durante la celebración del tercer aniversario de la Revolución de 1948

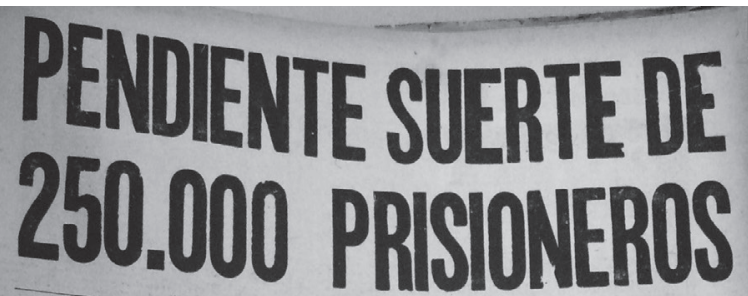
Diveriodectoy $\begin{aligned} & \text { Móviles Ulteriores de los Rojos } \\ & \text { Adviértense al Mantener Actitud } \\ & \text { Intransigente en Negociaciones }\end{aligned}$ Más de 40.000 Personas Vieron al Banfield

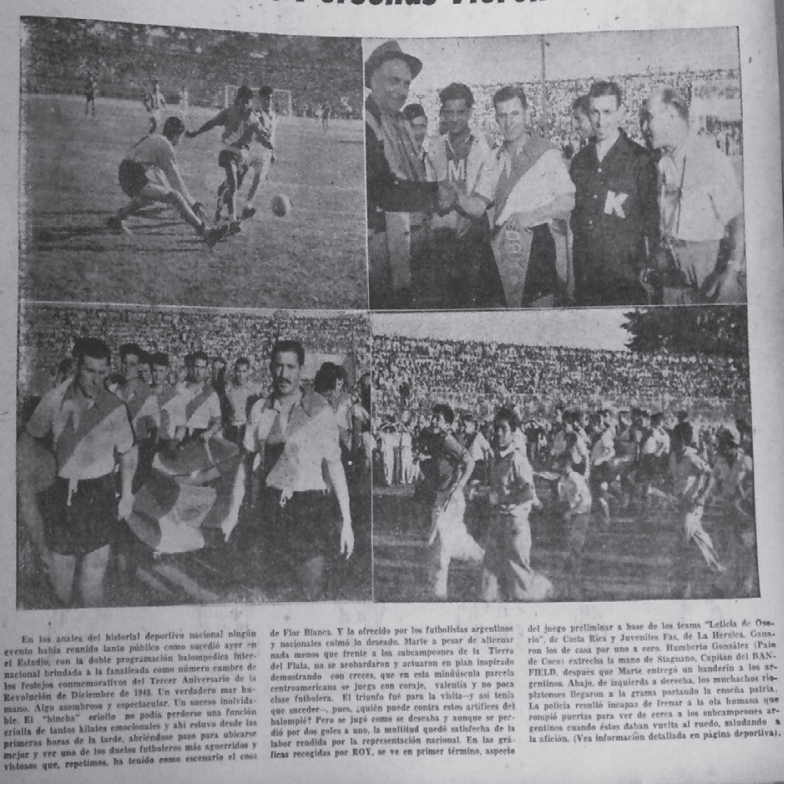

Fuente: El Diario de Hoy, 14 de diciembre de 1948. 
Fotos 6. Mitin del PRUD frente a un parque desconocido

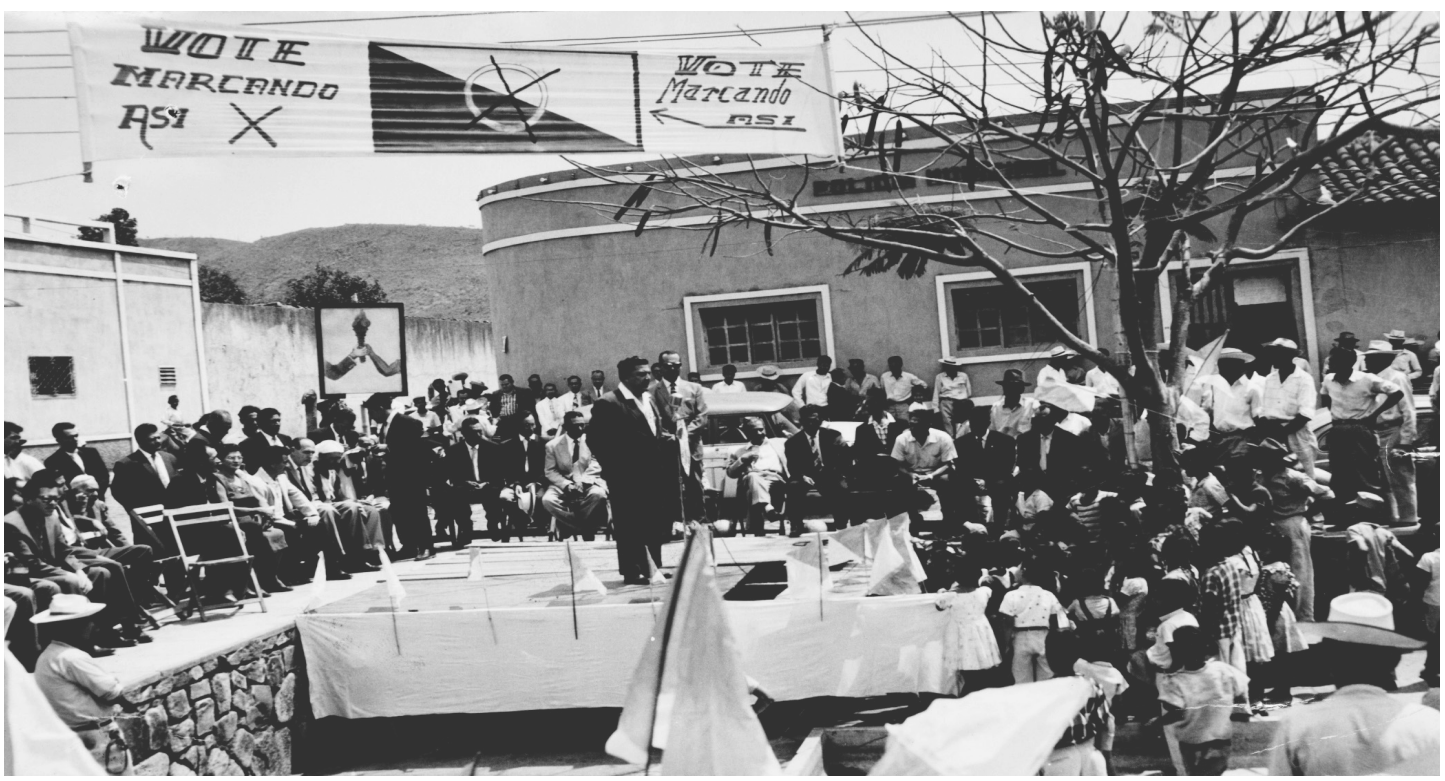

Fuente: Fototeca del Archivo General de la Nación de El Salvador.

Foto 7. José María Lemus reunido con miembros del PRUD

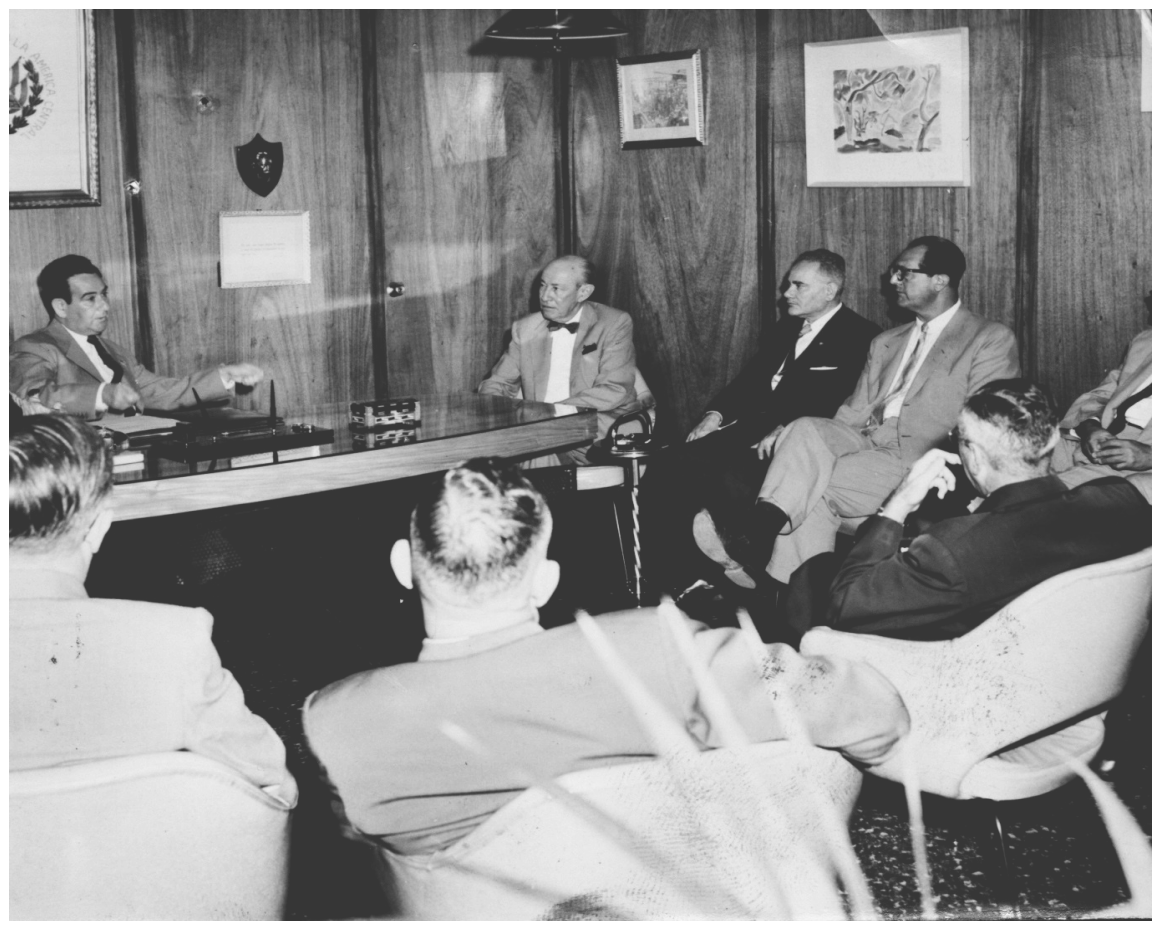

Fuente: Fototeca del Archivo General de la Nación de El Salvador. 